\title{
ІСТОРИКО-КУЛЬТУРНІ ТЕНДЕНЦІЇ РОЗВИТКУ \\ ПАРКОВОЇ КУЛЬТУРИ ВІННИЧЧИНИ КІНЦЯ ХХ - ПОЧАТКУ ХХІ СТ. (НА ПРИКЛАДІ ПАРКІВ-ПАМ'ЯТОК САДОВО-ПАРКОВОГО МИСТЕЦТВА МІСЦЕВОГО ЗНАЧЕННЯ)
}

\begin{abstract}
У статті теоретично осмислене поняття «паркова культура», досліджена ї̈ історико-культурна складова частина. На основі авторської концепції українських вчених розкрито зміст паркової культури, їі функціональні особливості і стратегічні пріоритети, серед яких головним є збереження історико-культурної спадщини. Проаналізовано міждисциплінарні підходи до розуміння історико-культурних тенденцій розвитку природнозаповідних територій, щзо дало змогу розкрити основні розбудовчі тенденції паркових територій $і$ зон. Відповідно до реєстру Природно-заповідного фонду України в статті зазначено, осмислено ірозкрито визначальнуроль $і$ значення парків-пам'яток садово-паркового мистеитва місиевого значення в сучасному культурному просторі Вінниччни. Наголошено на історико-культурному значенні кожного парку-пам'ятки садово-паркового мистецтва, визначено їхній соиіокультурний, економічний та туристичний потенціал. Зокрема, досліджено історико-культурний ресурс парків-пам'яток садово-паркового мистецтва місиевого значення Вінниччини, визначено основні історичні етапи їх розвитку відповідно до визначених у темі хронологічних межах, а саме: 1 етап (1985-1991 рр.) - період перебудови і розпаду СРСР; 2 етап (1991 р.-сьогодення) - становлення і удосконалення законодавства незалежної України; 3 етап (2014 - сьогодення) - реформа децентралізації. Зазначені етапи мають важливе історико-культурне значення для розвитку парків-пам'яток садово-паркового мистецтва, їх збереження. Розглянуто питання активної уваги та участі зацікавлених у розвитку парків-пам'яток садово-паркового мистеитва стейкхолдерів, доведено їх беззаперечну роль у відродженні, становленні і популяризації сучасної Вінниччини.
\end{abstract}

Ключові слова: паркова культура, історико-культурні тендениії, парки-пам'ятки садово-паркового мистецтва, етапи.

Butenko Victoria. Historical and cultural trends of development cultures of Vinnytsia region of the late $X X$ - the beginning of the XXI century (on the example of parks-monuments of landscape gardening art of local importance)

In the article, based on a theoretical understanding of the concept of "park culture", its comprehended historical and cultural component. Based on the author's concept of Ukrainian scientists, the content of park culture, its functional features and strategic priorities are revealed, among which the main one is the preservation of the historical and cultural heritage. Interdisciplinary approaches to understanding the historical and cultural trends in the development of nature reserves are analyzed, which made it possible to reveal the main trends in park areas and zones. According to the register of the Natural Reserve Fund of Ukraine, the article indicates, meaningfully and discloses the decisive role and significance of parks-monuments of landscape gardening art of local importance in the modern cultural space of Vinnytsia region. An emphasis is made on the historical and cultural significance of each park-monument of gardening art, their sociocultural, economic and tourist potential is determined. In particular, the historical and cultural potential of parksmonuments of landscape gardening art of local significance in the Vinnytsia region is investigated, the main historical stages of their development are determined in accordance with the chronological framework defined in the topic, namely: Stage 1 (1985-1991) - period restructuring and disintegration of the USSR; Stage 2 (1991 - present) - formation and improvement of the legislation of independent Ukraine, Stage 3 (2014 - present) - reform of decentralization. These stages are of great historical and cultural importance for the development of parks-monuments of gardening art, their preservation. The issues of active attention and participation of stakeholders interested in the development of parksmonuments of landscape gardening art are considered, their overwhelming role in the revival, formation and popularization of the modern Vinnytsia region is proved.

Key words: park culture, historical and cultural trends, parks-monuments of gardening art, stages.

Історико-культурна спадщина України, іiї ресурси набувають останні роки активного осмислення серед науковців і практиків, бо потенціал ії об'єктів зростає щодня з огляду на розвиток локальних туристичних зон і територій.

Особливого значення набуває розвиток паркової культури в містах, адже останні $\epsilon$ важливими осередками для забезпечення культурних, пізнавальних рекреаційних потреб як місцевих жителів, так і гостей міста. 
Розглядаючи паркову культуру як важливу історичну, культуротворчу складові частини в системі функціонування та розвитку сучасного місцевого простору, науковці наголошують на важливості збереження їх історико-культурного значення. Так, український культуролог О. Копієвська, досліджуючи паркову індустрію в системі розвитку вітчизняних та зарубіжних практик, пов'язує поняття «паркова культура» 3 давніми традиціями, іiі історико-культурним потенціалом і привабливістю. В авторських дослідженнях вчена наголошує на пріоритетності збереження історико-культурного значення паркової культури в світі, де «паркова культура, її розвиток стали обов'язковою компонентою гуманітарної політики, яка орієнтована на людину, iї потреби й інтереси»[8, с. 10].

Аналіз досліджень і публікацій із питань історико-культурних тенденцій паркових територій і зон дав нам змогу констатувати про переважний інтерес вчених до заповідних зон і визначається міждисциплінарним підходом до їх розгляду.

У такому контексті привертає увагу дослідження Л. Науменко, яка порушує проблему історико-культурних заповідників України через діалог сучасників із минулим. Дослідниця наголошує на важливості вивчення основних етапів становлення і розвитку історико-культурних заповідників, що своєю чергою актуалізує питання ролі і значення в цьому процесі так званої мови експонатів. Дослідниця досить слушно зазначає, що саме «феномен збирання, вивчення зібраних предметів і передавання цих знань іншим з часом дедалі більше наповнював широкий простір людини» [9, с. 34].

На поєднанні історико-культурного потенціалу та природних ресурсів паркових зон акцентує увагу В. Стельмах. Дослідник, осмислюючи природні та історико-культурні рекреаційні об’єкти Рівненщини, наголошує на важливості «створення комплексу спеціальних умов, які б сприяли ознайомленню рекреантів з особливостями природи, життя і побуту населення, культурно-історичними цінностями регіону рекреації» [13].

Активну увагу історико-культурному контексту розвитку рекреаційних ландшафтів приділяють представники географічних наук. Науковці наголошують на особливій ролі і значенні історико-культурних ресурсів у розвитку і функціонуванні рекреаційних ландшафтів, які, на їхню думку, мають потужний культурний та духовний потенціал. Науковці зазначають, що історико-культурні ресурси рекреаційних ландшафтів $є$ «основою для організації культурно-пізнавальних видів рекреаційної діяльності, виконуючи важливі виховні функції. До історико-культурних рекреаційних ландшафтів належать історичні, археологічні, архітектурні пам'ятки, твори монументального мистецтва, етнографічні особливості території, центри прикладного мистецтва та ремесел, музеї тощо» [6, с. 32].

На важливості правового та документального забезпечення наголошує В. Вечерський. Аналізуючи плани організації історико-культурних заповідників, вчений підкреслює важливість їх документального оформлення. На думку В. Вечерського, саме активні законодавчі зміни є загрозливими для збереження цілісності історико-культурних заповідників. Такі тенденції потребують уважного ставлення до науково-проектної документації, в якій визначають важливі для історико-культурних заповідників показники та технічні характеристики: «межі, зони охорони, обсяги і строки проведення робіт із консервації, реставрації, реабілітації, музеєфікації, ремонту і пристосування об’єктів культурної спадщини, благоустрою території заповідника, а також заходи з охорони і використання об'єктів культурної спадщини, збереження традиційного характеру» $[1$, с. 6$]$.

Таким чином, вищезазначене дає змогу зробити висновок про активний науковий інтерес до окреслення історико-культурних тенденцій розвитку об’єктів природно-заповідного фонду України, і характеризується такий інтерес міждисциплінарним підходом. При цьому варто наголосити, що історико-культурні тенденції паркової культури крізь призму становлення, розвитку і функціонування парків-пам'яток садово-паркового мистецтва місцевого значення не є активно досліджуваними серед науковців-істориків.

Активний розвиток туристичного потенціалу посилює роль і значення наукового осмислення історико-культурного потенціалу парків-пам'яток садово-паркового мистецтва для культурного, туристичного розвитку адміністративно-територіальних одиниць України. Його активне використання, а в деяких випадках відродження дасть змогу українським містам посилювати свою привабливість як для місцевих жителів, так і для гостей, туристів.

Одним із потужних туристичних ресурсів України є Вінниччина, яка має великий історико-культурний потенціал, особливе місце в якому належить паркам-пам'яткам садово-паркового мистецтва місцевого значення.

Так, відповідно до реєстру Природно-заповідного фонду України у Вінницькій області зареєстрована значна кількість парків-пам'яток садово-паркого мистецтва, які мають статус місцевого значення.

До переліку увійшли такі парки-пам'ятки садово-паркого мистецтва: 
Вінницька міська рада: Музей-садиба М. Пирогова, 1995 р. засн., П’ятничанський парк, 1972 р. засн., Парк Мала Софіївка, 1997р. засн., Парк ім. О.І. Ющенка, 1972 р. засн.; Погребищенський район: Васильківський, 1997 р. засн., Дендрарій лісово-дослідної станції, 1964 р. засн.; Жмеринський район: Дендрологічна ділянка, 1969 р. засн., Парк Браїловський, 1981 р. засн.; Мурованокуриловецький район: Михайлівський, 1972 р. засн., Парк Вікторія, 1995 р. засн., Парк Жван, 1995 р. засн.; Могилів-Подільський район: Парк Бронницький, 1985 р. засн., ЦПКіВ м. Могилів-Подільський, 1985 р. засн.; Шаргородський район: Парк Деребчинський, 1972 р. засн., Парк Рахнянський, 1972 р. засн., Парк Федорівський, 1972 р. засн.; Томашпільський район: Парк Комаргородський, 1972 р. засн., Парк Олександрівський, 1972 р. засн.; Жмеринський район: Парк Олександрівський, 1985 р. засн., Парк Северинівський, 1984 р. засн.; Калинівський район: Парк Саджавка, 1990 р. засн.; Тиврівський район: Парк Сутиський, 1984 р. засн.; Барський район: Парк-садиба Лугове, 1984 р. засн.; Немирівський район: Сокілецький, 1972 р. засн.; Погребищенський район, Спичинський, 1997 р. засн. [11].

Варто наголосити, що кожен із зазначених парків-пам'яток садово-паркового мистецтва має свою історію, визначається певними історико-культурними тенденціями розвитку, які потребують окремого детального вивчення і осмислення.

Розглядаючи історико-культурні тенденції як певну можливість становлення, розвитку, трансформації та функціонування досліджуваних у статті об'єктів, ми визначимо основні (загальні) напрями, за якими розвивалися парки-пам'ятки садово-паркового мистецтва місцевого значення з кінця XX ст. початку XXI ст.

Останнє десятиріччя XX ст. позначене в історії суттєвими геополітичними змінами, серед яких варто зазначити нові політичні реалії, а саме: з-поміж інших країн пострадянського простору була створена Українська незалежна держава. Своєю чергою початок XXI століття - це період України в умовах незалежності.

Визначені тенденції спираються на часові рамки становлення державного регулювання природнозаповідним фондом, а також основні засади та пріоритети культурної політики незалежної України від становлення до сьогодення.

1 етап (1985-1991рр.) - період перебудови і розпаду СРСР. Академік В. Смолій, аналізуючи в українському контексті горбачовську «перебудову», визначає рушійні зміни, наголошує на їх домінуванні. До них вчений зараховує «політику гласності та демократизації суспільного життя, введення елементів ринкових відносин, відмову від критики капіталізму, суттєве поліпшення відносин із США та країнами Західної Європи, спробу припинення «холодної війни» на рівні світової політики, визнання значущості загальнолюдських цінностей» [12, с. 8].

Проаналізувавши політичне становище УРСР напередодні незалежності, вчений А. Павлоський у роботі «Злет і крах соціалізму в СРСР: наслідки та уроки для України» наголошує на ролі і значенні релігійного, культурного, мовного, соціального питань. Науковець підкреслює важливість їх врахування у розв’язанні найважливіших проблем ідеології, моралі, культури [10].

Досліджуваний етап був складним і для сфери культури. Паркові території з їх усталеним юридичним статусом ніби перетікають із минулого в майбутнє з усіма традиціями, старими й новими проблемами. Відкриваються кордони, тим самим закладається підгрунтя для культурного обміну. Перед працівниками парків-пам'яток садово-паркого мистецтва в цей період постає низка проблем, серед яких - питання їх правового статусу, функціональні перспективи, що потребувало дослідження. Перед науковими співробітниками постала низка запитань, які, на жаль, залишалися без відповідей. Одним із перших питань $є$ юридичний статус парків-пам'яток садово-паркового мистецтва, що потребує правового підгрунтя.

2 етап (1991 р. - сьогодення). Цей етап характеризується становленням і подальшим удосконалення законодавства незалежної України. У цей період актуалізуються питання правового регулювання як культурної спадщини, так і сфери культури загалом. Зазначене в етапі сьогодення передбачає процес удосконалення правових норм (зміни, прийняття поправок), робота над якими триває протягом усього визначеного періоду. Вчені, досліджуючи питання правового регулювання відносин у сфері культури, виділяють специфічні особливості для культурної сфери. Так, дослідниця О. Копієвська, яка однією 3 перших розглядала питання культурної функції незалежної держави, іiї головних завдань і пріоритетів у незалежній Україні, наголошує на важливості цілеспрямованого, нормативно-організаційного опосередкування суспільних відносин державою, яке має здійснюватися за допомогою цілісної системи засобів, що забезпечують досягнення необхідних цілей (результатів), поставлених законодавець, видаючи юридичні норми. На думку вченої, «властивості правовідносин у сфері культури зумовлюють специфіку юридичного впливу на ці відносини, або метод правового регулювання. Метод правового регулювання вказує на те, як саме регулюються ці правовідносини» [7]. 
Правове регулювання парків-пам'яток садово-паркового мистецтва місцевого значення регулюються нормативно-правовими актами вищої юридичної сили, а саме: Конституцією України (1996 р.), законами України «Про природно-заповідний фонд України» (1992 р.), «Про охорону культурної спадщини» (2000р.), «Про благоустрій населених пунктів» (2005р.) «Про перелік пам’яток культурної спадщини, що не підлягають приватизації» (2008р.), «Про культуру» (2010р.). Вплив на функціонування парків-пам'яток садово-паркового мистецтва має Земельний кодекс України (2001р.)

Важливого історичного значення для розвитку і підтримки парків-пам'яток садово-паркового мистецтва мали такі нормативно-правові акти (нечинні): закони України «Про плату на землю» (1992р.), «Основи законодавства України про культуру» (1992р.), «Про затвердження Загальнодержавної програми збереження та використання об'єктів культурної спадщини на 2004-2010 роки» (2004р.), «Про Загальнодержавну програму формування національної екологічної мережі України на 2000-2015 роки» (2000р.) [5].

Досліджуваний етап визначається створенням досить потужного правового підгрунтя для збереження, розвитку і функціонування парків-пам'яток садово-паркового мистецтва як загальнодержавного, так і місцевого значення. Слід наголосити на ролі і значенні множинних підзаконних нормативноправових актів України, які з 1991 року й до сьогодення розвивали і деталізували основні правові норми щодо функціонування парків-пам'яток садово-паркового мистецтва. Для парків-пам'яток садово-паркового мистецтва місцевого значення Вінниччини цей етап визначався загальнодержавними тенденціями, які були характерні для всієї України.

3 етап (2014 - сьогодення) - реформа децентралізації. Стартом реалізації реформи став 2014 рік, якій позначився урядовим схваленням основного концептуального документа - Концепції реформування місцевого самоврядування та територіальної організації влади, - на основі якого було розроблено План заходів щодо іiі реалізації.

На урядовому порталі мета реформи визначається як «процес формування ефективного місцевого самоврядування та територіальної організації влади для створення і підтримки повноцінного життєвого середовища для громадян, надання високоякісних та доступних публічних послуг, становлення інститутів прямого народовладдя, узгодження інтересів держави та територіальних громад. Реформа передбачає відповідальність органів місцевого самоврядування перед жителями - за ефективність своєї роботи, а перед державою - за її законність» [4].

У рамках реформи відбулося добровільне об'єднання територіальних громад із відповідними повноваженнями, ресурсами та функціональним потенціалом. Одним із ключових питань реформи є переосмислення культурного потенціалу територій. Для відповідей, яких потребують об'єднані територіальні громади, започатковано проєкт «Децентралізація та реформа культурних послуг», який реалізовується громадською організацією «Товариство дослідників України», за підтримки Швейцарської агенції розвитку та співробітництва (SDC), у співпраці з Міністерством культури та інформаційної політики України та Асоціацією об'єднаних територіальних громад. Проєкт орієнтований на розробку нової політики у сфері управління культурою, а також запровадження нового підходу до надання якісних та доступних культурних послуг на рівні громади [3].

Парки-пам'ятки садово-паркового мистецтва місцевого значення є частиною Програм економічного і соціального розвитку Вінницької обласної ради, їх підтримка та розвиток розглядаються з урахуванням різних зацікавлених стейкхолдерів, і визначаються комплексним підходом до вирішення проблем.

Так, у рамках реформи з метою забезпечення ефективного функціонування та відповідного його забезпечення Департамент агропромислового розвитку, екології та промислових ресурсів Вінницької обласної ради створив «Карту розташування об'єктів природно-заповідного фонду Вінниччини». Створюються центри аграрної освіти, реалізуються природоохоронні заходи.

Парки-пам’ятки садово-паркового мистецтва стають об'єктом Планів перспективного розвитку громад, що дає змогу переглянути ресурсне забезпечення [2].

Варто звернути увагу, що парки-пам'ятки садово-паркового мистецтва Вінниччини активно досліджують вчені (І. Вітюк, В. Воловик, Ю. Клименко, В. Ковальський, Т. Михайленко, Б. Павличко, Н. Сиплива, В. Черняк, Ю. Яценюк), наукові доробки яких є вважливими і перспективними для розвитку історико-культурних, рекреаційних, туристичних перспектив поєднаних територіальних громад та їхніх паркових ресурсів.

Розгляд історико-культурних тенденцій розвитку паркової культури Вінниччини кінця XX ст. початку XXI ст. на прикладі парків-пам'яток садово-паркового мистецтва місцевого значення уможливив певні висновки.

Паркова культура є важливим історико-культурним, туристичним ресурсом розвитку Вінниччини, розвиток якої у визначений у статті період передбачав три основних історичних етапи. Усі етапи мали 
своє історико-культурне значення для розвитку парків-пам'яток садово-паркового мистецтва, зокрема міського.

Вінниччина, ii історико-культурна спадщина крізь призму функціонування парків-пам'яток садовопаркового мистецтва як унікальний культуротворчий, пізнавальний, рекреаційний, дослідницький, туристичний ресурс є об'єктом дослідження вчених та практиків, представників різних наукових течій, що своєю чергою дає змогу осмислити сучасні тенденції розвитку та перспективного використання різного функціонального призначення.

Активна увага всіх зацікавлених у розвитку Вінниччини стейкхолдерів до порушеної в статті проблеми дасть змогу популяризувати культурну спадщину області, посилити іiі іміджевий і економічний показники.

\section{Лiтература:}

1. Вечерський В.В. Історико-культурні заповідники: плани організації території. Сіверщзина в історії Украӥни : збірник наук. пр. Київ - Глухів, 2010. Вип. 3. С. 6-10.

2. Вінницька обласна державна адміністрація. URL: http://www.vin.gov.ua/ (дата звернення : 20.12.2020).

3. Децентралізація та реформа культурних послуг : онлайн-презентація та обговорення результатів проекту. URL: https://decentralization.gov.ua/news/12522 (дата звернення : 15.11.2020)

4. Ефективне врядування. Урядовий портал. Єдиний веб-портал органів виконавчої влади України. URL: https://www.kmu.gov.ua/diyalnist/reformi/efektivne-vryaduvannya/reforma-decentralizaciyi (дата звернення : 15.12.2020)

5. Законодавство України. Верховна Рада Украӥни. Офіційний веб-портал парламенту України. URL: https:/zakon.rada.gov.ua (дата звернення : 25.12.2020)

6. Кисельов Ю.О., Ужела М.І. Історико-культурні рекреаційні ландшафти Прикарпаття. Охорона довкілля : збірник статей XV Всеукраїнських наукових Таліївських читань. Харків, 2019. С. 32-34.

7. Копієвська О. Правове регулювання відносин у сфері культури. Право Украӥни. 2004. № 8. С. 82-85.

8. Копієвська О.Р. Паркова індустрія : підручник. Київ : НАКККіМ, 2015. 220 с.

9. Науменко Л. Історико-культурні заповідники України - діалог сучасників з минулим мовою експонатів. Наукові записки з украӥнської історії. 2012. Вип. 32. С. 34-38.

10. Павловський А.А. Злет і крах соціалізму в СРСР: наслідки та уроки для України. Київ : Кий, 1999.174 с.

11. Природно-заповідний фонд України. URL: https://pzf.land.kiev.ua/pzf-obl-2.html (дата звернення : 25.12.2020)

12. Смолій В. Горбачовська «перебудова»: український контекст (до 30-річчя проголошення курсу). Україна XX століття: культура, ідеологія, політика. 2016. Вип. 21. С. 8-11.

13. Стельмах В. Природні та історико-культурні рекреаційні об'єкти Рівненщини. Вісник Львівського університету. Серія географічна. 2013. Вип. 43. Ч. 1. С. 92-98. 